\title{
Emosyonel Yeme
}

\author{
Güzin Mukaddes Sevinçer ${ }^{1}$, Numan Konuk²
}

ÖZET:

Emosyonel yeme

Emosyonel yeme olumsuz duygulara ikincil așırı yeme eg̃ilimini anlatan bir kavramdır. Emosyonel yeme ilk başlarda bulimik hastaların aşırı yemelerini destekleyen bir etmen olarak emosyonların yer aldıg̃ı bir tablo içinde bulimia ile birlikte anılmıștır. Sonrasında ise tıkınırcasına yeme ataklarının da emosyonel yeme ile ilișkili olabileceg̃i gösterilmiștir. Olumsuz duygular karşısında gözlenen bu aşırı yeme tepkisi; obez bireylerde, yeme bozuklug̃u olan kadınlarda ve normal kilolu olup da diyet yapan kișilerde mevcut oldug̃u gösterilmiștir. Özellikle kilo verme girișimlerinde yeme davranışlarının düzenlenmesinde emosyonel yemenin önemi giderek artmaktadır. Psikiyatrik bozukluklarda gözlenen yeme ve kilo deg̃ișiklikleri, ilaç yan etkileri ile ilișkili ya da ilișkisisiz metabolik sendrom ve diabet, ve kilo verdirici tedavilerle iç içe geçen psikososyal konular da dikkate alındığında emosyonel yeme kavramının daha kapsamlı araștııılması gerekliliḡi așikardır.

Anahtar sözcükler: emosyonel yeme, tıkınırcasına yeme, şişmanlık, yeme bozuklukları

Journal of Mood Disorders 2013;3(4):171-8

\section{ABSTRACT: \\ Emotional eating}

Emotional eating is a concept which describes a tendency towards overeating in response to the negative emotions. Emotional eating was initially recognized along with bulimia that emotions taken as a factor which reinforces the over-eating of bulimic patients. Later on, it was found out that binge eating itself could also be related to emotional eating. Emotional eating is prevalant in people who have obesity, women with eating disorders, and people who have a regular weight but are on diet. The concept of emotional eating is becoming increasingly important, especially in the interventions for weightloss management. Considering the issues such as eating disorders and weight changes in psychiatric disorders, diabetes and metabolic syndrome- no matter relation with the side effects of drugs, and psycho-social issues entangled with weight-loss management, makes it obvious that the concept of emotional eating demands more research.

Key words: emotional eating, binge eating, obesity, eating disorders

Journal of Mood Disorders 2013;3(4):171-8
${ }^{1} M D$, Gelisim Üniversitesi, iisBF Psikoloji Bölümü, îstanbul-Türkiye ${ }^{2} \mathrm{MD}$ Cerrahpasa Tip Fakültesi, Psikiyatri Anabilim Dalı, İstanbul-Türkiye

Yazıșma Adresi / Address reprint requests to: Güzin Mukaddes Sevinçer

Gelișim Üniversitesi, iisBF Psikoloji Bölümü, istanbul, Türkiye

Telefon / Phone: +90-212-422-7000

Elektronik posta adresi / E-mail address: guzinsevincer@yahoo.com

Kabul tarihi / Date of acceptance: 26 Eylül 2013 / September 26, 2013

\section{Bag̃ıntı beyanı:}

G.M.S., N.K.: Yazarlar bu makale ile ilgili olarak herhangi bir çıkar çatıșması bildirmemiștir.

\section{Declaration of interest:}

G.M.S., N.K.: The authors reported no conflic of interest related to this article.

\section{GİRIŞ}

Vücut ağırlığı; gıda tüketimi yoluyla enerji alımı ve bu enerjinin harcanması arasındaki karmaşık dengeye dayanmaktadır. Bu enerji dengesi santral sinir sisteminde hipotalamus gibi belirli beyin bölgeleri tarafından yürütülür. Kluver Bucy Sendromu gibi yeme davranışının farklılaştığı uç örnekler yeme davranışında santral sinir sisteminin rolünü ortaya koymaktadır (1). Üniter bir fenomen olarak ele alındığında depresyon gibi mizaç bozukluklarında da kilo değişiklikleri ile sonuçlanan yeme davranışı değișiklikleri gözlenmektedir. Depresyonda klasik olarak beden ağırlığının azalması ile sonuçlanan kilo ve iștah kaybı gözlenirken bir alt tip olan "atipik depresyonda" ise artmaktadır. Bu bilgilere rağmen yeme davranışında emosyonların etkisinin özgün konumu ağırlıklı olarak yeme bozuklukları, obezite ve diyabet konularında yapılan araştırmalar dolayısıyla gündeme gelmektedir.Mizaç bozukluklarında gözlenen yeme davranışı değişiklikleri bile modern psikiyatrik anlayışta yeterince araştırılmamış ve ayrıştırılamamışken diğer alanlarda yapılan bu araştırmalardan anlamlı bir bütünlük içinde sonuç elde etmek güçleşmektedir (2). Bu sebeple bu derleme yazısında yeme davranışı ve mizaç ilişkisinin anlaşılmasına katkısı göz önünde bulundurulup, özgül olarak "emosyonel yeme” konusundaki literatür gözden geçirilmiştir.

Emosyonel yeme olumsuz duygulara ikincil aşırı yeme eğilimini anlatan bir kavramdır. Emosyonel yeme ilk başlarda bulimik hastaların aşırı yemelerini destekleyen bir etmen olarak emosyonların yer aldığı bir tablo içinde 
bulimia ile birlikte anılmıştır. Sonrasında ise tıkınırcasına yeme ataklarının da emosyonel yeme ile ilişkili olabileceği gösterilmiştir. Özellikle kilo verme girişimlerinde yeme davranışlarında emosyonel yemenin önemi giderek artmaktadır (3). Bu yazı çerçevesinde emosyonel yemenin tanımı, sıklığı, obezite ve yeme bozuklukları içindeki yeri ve ilgili teoriler gözden geçirilecektir.

\section{Emosyonel Yeme}

İster olumlu ister olumsuz nitelikte olsun, emosyonel uyarının yeme davranışı değişikliklerine yol açtığı öteden beri yaygın kabul görmüştür $(4,5)$. Olumsuz emosyonlar veya stres durumunda gözlenen fizyolojik reaksiyonlar beslenme sonrası oluşan tokluk hissine benzediği için, olumsuz duygular karşısında iştah kaybı ve gıda alımının azalması doğal bir fizyolojik yanıt olarak kabul edilmiştir (6). Buna karşılık, olumsuz duygusal uyaranlar karşısında gıda alımında artış ise "emosyonel yeme" olarak adlandırılmış ve 'yersiz' bir tepki olarak ele alınmıştır (7). Olumsuz duygular karşısında gözlenen bu aşırı yeme tepkisinin; obez bireylerde (8), yeme bozukluğu olan kadınlarda (9) ve normal kilolu olup da diyet yapan kişilerde $(10,11)$ mevcut olduğu gösterilmiştir. Bu nedenle, duygular ile yeme ilişkisinin en azından kısmen kişiye bağlı belirli özelliklerden etkilendiği ileri sürülmektedir (5-6).

\section{Tanım ve Sıklık}

Emosyonel yeme açlık hissi nedeniyle ya da öğün zamanı geldiği için ya da sosyal gereklilik olduğu için değil de sadece ve sadece duygulanıma cevaben ortaya çıktığı varsayılan yeme davranıșı olarak kavramsallaştırılmıștır (11). Emosyonel yemenin olumsuz emosyonlar tarafından tetiklendiği, sıklıkla gizlice yapıldığı ve dış ortamlarda değil evde yapıldığı gösterilmiştir. Emosyonel yeme sıklıkla düşük benlik saygısı, yetersizlik duyguları ve yeme bozukluklarıyla ilişkilendirilmiştir $(12,13)$. Aynı zamanda emosyonel yemenin kilo kontrolü düşük ve beden kitle indeksi (BKİ) yüksek kişilerde daha sık olduğu ortaya konmuştur (14). McCrone ve ark. (2000) yaptıkları çalışmada erken başlangıçlı obezitesi olan kadınlarda olumsuz duygulanıma cevaben yemenin ve açlıktan ziyade duygusal uyarılma nedeniyle yemenin daha sık olduğunu göstermişlerdir (15). Emosyonel yeme normal kilolu kişilerde de görülebilir ve bulimik yeme tutumları ile de ilişkilidir.
Emosyonel yemesi olan kişilerin pekçoğunda bu davranışın uygunsuz başetme stratejisinin bir sonucu olduğu ileri sürülmüştür (16-18).

\section{Emosyonların Yeme Davranışına Etkileri}

Yeme davranışı emosyondan oldukça etkilenen bir olgudur. Öğünlerin sıklığının, ne miktarda yendiğinin ve ne yendiğinin psikolojik ihtiyaçlarla ilişkisi olduğu çeşitli araştırmalara konu olmuş ve kuvvetli bir ilişkinin varlığı kabul edilmiştir. İnsanın yeme davranışının emosyonel durumdaki değişimlerle paralellik gösterdiği yaygın kabul edilen bir görüştür. Mehrabian gıda alım miktarı ile farklı emosyon türleri arasındaki ilişkiyi araştırmıştır. Buna göre fazla gıda alımı sıkıntı, depresyon, yorgunluk emosyonları sırasında olurken, az miktarda gıda alımı ise korku, gerilim ve ağrı emosyonları ile ilişkili bulunmuştur (19). Lyman olumlu emosyonlar sırasında sağlıklı gıda alımına eğilim varken, olumsuz emosyonlar sırasında ise zararlı gıda alımına yönelimin daha fazla olduğunu göstermiştir (20). Patel ve Schlundt olumlu ve olumsuz mizaçta nötral mizaca göre belirgin olarak daha fazla yemek yendiğini ve olumlu mizacın olumsuz mizaca göre gıda alımı üzerine daha belirleyici bir etkiye sahip olduğunu bulmuşlardır (21). Macht öfke, korku, mutsuzluk ve neşenin yeme davranışı üzerine farklı etkilerini incelemişlerdir. Bu araştırmada deneklerin öfke ve neşe sırasında korku ve mutsuzluğa göre daha fazla düzeyde açlık hissettiklerini ortaya konmuştur. Öfke sırasında hızlı, düzensiz ve ne bulursa onu yeme tarzında özensiz yeme ile karakterize dürtüsel yemede artış gözleniyorken, neşe sırasında ise gıdaları lezzetli olduğu için yeme ya da sağlıklı olduğu düşünülen gıdaları tüketme tarzında hazcı hedonic- yemede artış gözlenmiştir (22).

\section{Gıdaların Mizaç Üzerine Etkisi}

Gıdaların da mizaç üzerine etkisini araştıran araştırmalar bulunmaktadır. Yemek yemenin haz veren ve ödül sistemini ilgilendiren özellikleri nedeni ile olumlu duyguları ortaya çıkartan ve iyilik hali hissettiren bir yönü bulunmaktadır. (23-25). Gıdaların emosyonel etkilerinin obez hastalarda normal kilolu olanlara göre daha belirgin olarak gözlenebildiğini ortaya konmuştur (26). Obezler normallere göre gıda ile ilgili koku veya güzel görünüm gibi dışsal etkilere daha açıktır. Güzel kokulu ve görü- 
nümlü gıdalar obez bireylerde yeme davranışını değiştirmek bakımından daha etkilidir (27).

\section{Emosyonel Yeme İle İlgili Teoriler}

Olumsuz duygulanımla aşırı yemenin ilişkisini ortaya koyan tüm bu araştırmalara rağmen hangi mekanizma ile ve hangi olumsuz duyguların aşırı yemeyi ortaya çıkardığı net olarak bilinmemekte olup bir kısım teoriler öne sürülmüştür. Emosyonel yeme davranışının özellikle kilo almaya katkısı, kilo verdirici tedaviler sırasında olumsuz bir etken gibi görüldüğünden ilgili teoriler ağırlıklı olarak obezite araștırmaları üzerine şekillendirilmiștir.

Psikosomatik teori emosyonel tarzda yiyen obez kişilerin, emosyonları hakkında farkındalıklarının olmadığı ve duygulanımı tanıma becerisinin bulunmadığını öne sürer (8). Bu teoriye göre emosyonel yiyiciler iştah gibi içsel uyaranlara ya da açlık ve tokluk hislerine cevap olarak değil emosyonlarına cevap olarak yerler.

Kaplan ve Kaplan'in obezite teorisi; bu teoriye göre obez kişiler gergin ve sıkıntılı olduklarında anksiyetelerini azaltmak için aşırı yemektedirler. Yemenin anksiyeteyi hangi mekanizmayla azalttığı tam anlaşılamamıștır fakat protein ve karbonhidrat alımının beyinde nörotransmitter, özellikle de serotonin sentezi üzerine etki edebileceği üzerinde durulmuştur. Bu kişilerin anksiyöz olunmayan nötral durumları sırasında beslenme ile doyuma ulaşma ilişkisini erken yaşta öğrenmiş olmaları bu teorinin temelini oluşturmaktadır. Obez bireyler açlık hissi ve anksiyeteyi birbirinden ayırt edememektedirler. Bu bireyler açlığa cevap olarak yedikleri gibi anksiyeteye cevap olarak da yeme davranışını öğrenmişlerdir. Sonuç olarak anksiyeteyi azaltan kompulsif aşırı yeme de obeziteye yol açmaktadir (28).

Bruch'ın teorisi ise yanlış açlık farkındalığı ile aşırı yemeyi ilişkilendirmiştir. Bu teori ile de açlık yaşantısının sadece içgüdüsel olmadığına yani öğrenilmiş bir tarafı olduğuna da dikkat çekilmiştir. Obez bireylerde beslenme ve diğer bedensel ihtiyaçların giderilmesi çerçevesinde gerçekleşen deneyimler ve kişilerarası olaylar hatalı değerlendirilmiştir. Hatalı ve kafa karıştırıcı erken yaşantılar açlık ve doyma hissini tanımlama ile ilgili becerilerin içiçe geçmesine sebep olur. Bu bireyler ne açlıklarını ne de tokluklarını anlayamazlar, aynı zamanda gıda alma arzusunu da nahoş duygu ve hislerden ayrıştıramazlar. Bu kişiler farkındalıkla ilgili doğru içsel programlamaları olmadığından ne zaman ve ne kadar yiyeceklerini anlamak için dışsal bir kısım sinyallere ihtiyaç duyarlar. Sonuçta bu teoriye göre kişiler emosyonel gerginlik ve rahatsız edici hisleri olduğunda aşırı yemeye yönelir (29). Hem Kaplan'ın hem de Bruch'ın teorisi ortak bir çıkarıma ulaşmışırı; "obez kişiler rahatsız edici emosyonel durumlara cevaben yemek yerler.”

Schachter'in "içseldişsal" obezite teorisi: Korku ve anksiyetenin fizyolojik belirtileri normal kilolu kişilerde gıda tüketimlerini bastırıcı etkiye sahipken obez bireylerde içsel uyaranlara bir duyarsızlık olduğundan dolayı bu durum gerçekleşmez. Bruch'ın teorisindeki gibi bu teoride de açlığın fizyolojik tesirleri gibi bazı yönlerinin öğrenilmiş olduğu ancak bunun obez kişilerde öğrenilemediği ifade edilmektedir. Stres sırasında midedeki kasılmalar azalır ve bu durum normal kilolu bireylerde yeme davranışını azaltır, ancak obez bireylerde ise bu gerçekleşmez. İçsel fizyolojik uyarıcıları anlamada eksiklikleri olduğu için obez bireyler yemeyi başlatma ve durdurmada dışsal uyaranlara ihtiyaç duyarlar. Bu kişiler yiyeceklerin dışsal uyarılarına daha duyarlıdır ve açlık-tokluk hissinden ziyade, bu dışsal uyarılara cevaben yerler (30).

Kısıtlama teorisi: Diyet yapma davranışı tam ters bir etki ile tıkınırcasına yemeye yol açarak aşırı kiloya sebep olabilir. Bu alanda çalışma yapan hemen her araştırmacı obez bireylerin gıda alımını kısıtlama uğraşı içinde olduğunu gözlemlemiş ve takiben diyet yapmanın normal kilolular ya da obez kişilerdeki etkisinin nasıl farklılaştığı sorusu ilgi uyandırmıştır. Kısıtlama teorisi ilk kez Hernan ve Mack tarafından ele alınmış sonrasında Herman ve Polivy tarafından geliştirilmiştir (31-32). Bu teoriye göre gıdalara karşı duyulan arzu ile bu arzuya direnme çabası yeme davranışımızı belirler ve kısıtlama, bu arzuya karşı gösterilen bir kognitif çabadır. Kısıtlayıcı yeme davranışı olanlar sürekli çok yediklerinden yakınırlar ve kilolu olmaktan kaçınmak için sürekli yeme davranışını kısıtlarlar. Kısıtlayıcı davranışı olmayanlarda bu korku yoktur, gıda alımının sonuçlarından endişe etmezler. Aynı teoride yer alan“dizinhibisyon hipotezi”ne göre ise kısıtlamalı tarzda yiyenlerin kendini kontrolü, bazı olaylar sonucunda geçici olarak bozulabilir. Araştırmalarla da doğrulanan bu olaylar, anksiyete ve depresyon gibi güçlü emosyonel durumlar, aşırı yediğine dair algı gibi kognisyonlar ve alkol tüketimi gibi sebeplerdir. Bu teoride en ilgi çeken 
nokta, aşırı yediği algısının kısıtlayıcı yemeyi sekteye uğrattığı görüşüdür. Bu görüşün aksine Waller ve Osman ise kısıtlayıcı yeme tutumu ile emosyonel yeme arasında güçlü bir ilişki olmadığını göstermişlerdir(33).

Kaçış teorisi: Bu konuda son bir teori ise emosyonel aşırı yemenin olumsuz farkındalık yaratan ortamlardan bir kaçış mekanizması olarak kullanıldığı şeklindeki teoridir (34). Kaçış teorisi aşırı yeme tepkisinin, kendilikle ilgili farkındalığı değiştirebilecek nitelikteki egoyu tehdit eden uyaranlardan kaçma veya dikkati bu uyaranlardan çeldirme için sergilendiğini öne sürmektedir. Bu görüşe göre self, benliği tehdit eden bir bilgi ile karşılaştığında olumsuz duygular ve onun getirdiği caydırıcı etkilerden uzaklaştırmak için emosyonel yiyicileri kaçmaya yöneltir. Bu kişiler farkındalıktan kaçışı, aşırı yeme ile sonuçlanan daha belirgin nitelikteki dış uyaranlara dikkatlerini yöneltmek suretiyle yaparlar. Yüksek düzeyde farkındalığın aşırı yeme davranışına katkıda bulunduğunu gösteren araştırma da mevcuttur. (35).

Genel olarak bakıldığında emosyonel yiyen kişiler yeme davranışlarını, olumsuz emosyonlar ya da stresten kurtulmak için başetme yöntemi olarak kullandığı ve sonuç olarak bu davranışın problemli bir hale dönüştüğü söylenebilir $(16,17,36,37)$. Bu teorilerde öne sürülen emosyonel yemenin olumsuz duygulanımdan kaçmak için ortaya çıktığı yönündeki görüşler en azından kısmen başka bir durumla, başetme biçimleri ile de ilişkilidir. Başetme biçimlerinden özellikle emosyon yönelimli ve kaçınmayı kullanan stratejiler sıklıkla diyet yapma, tıkınırcasına yeme ve bozuk yeme tutumları ile ilişkili bulunmuştur (18).

\section{Yeme Bozuklukları ve Emosyonel Yeme}

Duygulanıma cevaben yeme obeziteden başka, tıkınırcasına yeme bozukluğu ve bulimiya nervoza ile ilişkili bulunmuştur. $(36,38,39)$. Yapılan bazı kesitsel ve prospektif çalışmalar hem klinik dışı hem de yeme bozukluğu olan örneklemde kadınlarda tıkınırcasına yeme ile emosyonel yeme arasında bir ilişki olduğunu göstermektedir $(40,41)$. Kiz ergenlerde emosyonel yemenin gelecek tıkınırcasına yeme ataklarının önemli bir öngörücüsü olduğugösterilmiștir (40).Yeme bozukluğu olan kişilerde yapılan bir araştırmada olumlu emosyonların yeme ataklarının sayısını ve tıkınırcasına yemeyi öngörebildiği gös- terilmiştir (42).

Emosyonel yeme ve tıkınırcasına yeme birbirleriyle yüksek derecede ilişki sergilemekte ve sıklıkla da birlikte görülmektedir. Tıkınırcasına yeme bozukluğu (TYB) bulimiya nervozaya özgü, düzenli uygunsuz dengeleyici davranışların olmadığı, aynı zaman diliminde ve benzer koşullardaki bireylerin yiyebileceklerine göre daha fazla miktarda yiyeceğin belirli bir sürede (örneğin 2 saatte) yenilmesi ve bu dönemde kontrol kaybı duygusunun olduğu bir tablodur. DSM IV-TR'de tıkınırcasına yeme ortalama olarak 6 aylık sürede en az haftada 2 gün ortaya çıkar denilmekte iken DSM 5'te bu süre 3 aylık sürede en az haftada $1 \mathrm{kez}$ olarak değiştirilmiştir (43).Emosyonel yemede de, emosyonlar tıkınırcasına yeme ataklarındaki gibi ne miktarda gıda tüketileceğinin belirleyicisi ve kontrol duygusunun kaybı ile ilişkili yeme davranışının bir belirleyicisi bir kavramdır. Mevcut literatürde emosyonel yemenin tıkınırcasına yeme bozukluğundan ayrı geçerli bir antite olduğu ileri sürülmüştür.

Öte yandan emosyonel yemenin tıkınırcasına yeme ve bulimia ile ilişkisi kısıtlama teorisi çerçevesinde de ele alınmıştır. Bulimiyadaki tıkınırcasına yemenin kısıtlama davranışı sonucu gelişmiş olabileceği ileri sürülmüştür. Bir araştırmada TYB olan kişilerde emosyonel yeme skorları TYB olmayanlara göre daha yüksek bulunmuştur (44). Emosyonel yeme TYB için belirgin bir öngörücü faktördür. Kısıtlayıcı yeme skorlarında ise TYB olan ve olmayan bireyler arasında beklenildiği üzere bir fark saptanmamiştır (44).

Bulimik vakalar incelendiğinde bu kişilerin hastalık başlangıcından önce kısıtlayıcı yeme davranışı içinde bulundukları ve araya giren başka etkenler nedeni ile aşırı yemelerinin olduğu saptanmıștır. Çoğu vakada bulimiya hastalığının diyetten birkaç ay sonra başladığı gözlenmiştir. Diyeti sekteye uğratıp tıkınırcasına yeme ataklarına sebep olan ise anksiyete, depresyon ve gerginlik gibi emosyonel durumlardır (45). Çalışmalar tıkınırcasına yemenin bu olumsuz duyguları azalttığını da göstermektedir (food and emotion). İlk dönem araştırmalarda emosyonel yeme sıklıkla tıkınırcasına yemesi olan obez populasyonda araştırılmış olup, tıkınırcasına yemesi olmayanlarda daha az araştırılmıştır (46). Emosyonel yeme davranışı daha çok öğün zamanlarında değil zamansız atıştırmalarda daha sık gözlenmektedir. Bundan dolayı atıștırma davranışı sergileyen kişilerin, gıdaları emosyonu düzenlemek için bir araç gibi kullandığı sonucuna varıl- 
mıştır (34). Ayrıca son yıllarda dikkat çeken diğer bir antite; gece yeme sendromunun da emosyonel yeme ile ilişkili olduğu gösterilmiştir (47).

\section{Obezite ve Emosyonel Yeme}

Tıkınırcasına yeme davranışı obezitenin sürmesinde önemli bir kavram olarak tartışılmıştır. Bu davranışın altında diyette kısıtlama yapmak ve dışsal etmenlerin etkileri yanında emosyonel yemenin de tıkınma davranışını izah edip edemeyeceği araştırılmıştır. DSM'de tarif edildiği üzere tıkınırcasına yeme dönemleri depresyon ve anksiyete gibi disforik mizaç nedeni ile tetiklenebilir. Buna rağmen bu durumun sıklı̆̆ı, hangi duyguların tetikleyici olduğu ve emosyonla aşırı yemeye hangi etkenlerin eşlik ettiğine ait bilgilerimiz yine de azdır. Arnow ve ark.'1 obez bireylerde yeme ve emosyon ilişkisine dair yeterli bilgi bulunmamasını birkaç sebeple izah etmişlerdir. Öncelikle obez bireylerin içsel uyaranlardan çok dışsal uyaranlarla yemeye eğilimlerinin arttı̆̆ını kabul eden kökü yıllara dayanan eski anlayışın varlığıdır. Emosyonlarla tetiklenen yeme bu paradigmaya ters düşmektedir. Çünkü emosyonlar aslen dişsal değil içsel uyaranlardır. İkinci olarak hakim yeme bozuklukları teorisi görüşünde tıkınırcasına yemeyi ortaya çıkartan ana faktör kısıtlama davranışı olup diyete eşlik eden duygular ikincil dereceden önemli kabul edilmiş ve dikkate alınmamıştır. Tıkınırcasına yeme aracısız yani emosyonlardan ayrı olarak başıı başına ele alınmıştır. Emosyonların eşlik edici ya da önceleyen rolü gözardı edilmiştir. Son olarak psikanalitik literatürün tıkınırcasına yeme hakkındaki izahlarının bu konuya başka türlü bilimsel yaklaşımların olabileceği düşüncesini ihmal eden, böylece yeni araştırmaların önünü tıkayan anlayışıdır (39).

Bazı çalışmalar obez bireylerin gıdaların renk ve koku gibi sensoriyel özellikleriyle uyarıldıklarını göstermiştir (48). Gıdalardan zengin uyaranlara maruz kalan obez kişiler aşırı yemeye eğilim gösterirler. Emosyon düzenlemesi yani duygulanımın yeme davranışını kontrol ettiği teorisine göre (49-51), kişiler olumsuz duygulanımlarını azaltmak için yemek yerler. Bazı kişilerin mutsuzluklarını azaltmak için dondurma yemeye yöneldikleri gösterilmiştir (52). Obez bireylerde depresif belirtiler sık görülür (53).İşte obez bireylerin bu şekilde gıda alımına yönelmesi olumsuz duygulanımlarını azaltmak için kullandıkları bir başetme yöntemi olarak yorumlanmıştır (54). Pek çok çalışma diyet yapan obez bireylerde diyet yapmayan obezlere göre daha fazla olumsuz duygulanım olduğunu ortaya koymuştur (26). Obez bireyler zaten sürekli diyet yapmaya eğilimli olduklarından (55), kiloyu kontrol etmek amacıyla yöneldikleri zihinsel kısıtlama çabası olumsuz duygulanımları için önemli bir kaynak olmaktadır. Üstelik bu tarz olumsuz duygulanımlar yeme üzerindeki kontrolsüzlük ile de ilişkili bulunmuştur (32). Diyet yapan obez kişilerin yapmayan obezlere göre olumsuz duygulanım karşısında gıda tüketimine daha fazla yöneldikleri gösterilmiştir (5). Bu kişiler zaten daha fazla olumsuz duygulanıma, gıdalar üzerindeki kontrolünü daha fazla kaybetmeye ve neticede aşırı gıda tüketimine daha yatkındır (57). Obez kişiler, öfke (58), can sıkıntısı (38), kaygı, stres (35), depresyon ve yanlızlık (4) gibi olumsuz duygular karşısında gıda alımını arttırır ve aşırı gıda tüketirler. Halbuki obez bireylerin aksine normal kişilerde olumsuz emosyonların gıda alımını azalttığı kabul edilmektedir (32). Bunun aksini söyleyen araştımalar da mevcuttur. Örneğin Bellisle ve ark. bir grup denekte olumsuz duyguların yemeyi arttırdığını diğer grupta ise azalttığını göstermiştir (59). Özetle ifade edilecek olursa normal kilolu kişilerin duygulanıma cevaben yeme davranışının nasıl etkileneceğini konusunda net bir bilgi yoktur. Fakat ister diyette olsun ister olmasın obez bireylerde özellikle de olumsuz duygulanımın yeme davranışını arttırdığı gözlenmektedir $(60,61)$.

Obez bireylerde yeme davranışı ile emosyonlar arasında özel bir ilişki olduğu ortaya konulmakla birlikte bugüne kadar yapılan araştırmalar öfke, korku, mutsuzluk, mutluluk gibi sadece temel birkaç duygu üzerinde durmuştur. Ayrıca gıdaların tesiri bakımından yapılan değerlendirme de sadece hoşlandım, hoşlanmadım şeklinde değerlendirilmiştir. Temel emosyonların duyusal informasyona fizyolojik reaksiyonu temsil ettiğine dair eski görüşe karşılık gıdalar karşısında ortaya çıkan kompleks emosyonların bu kadar az sayıda emosyonla izah edilemeyeceği de öne sürülmüştür $(62,63)$.

\section{Aleksitimi ve Emosyonel Yeme}

Emosyonel yemenin bilinçli ve bilinçsiz komponentleri olduğu söylenebilir. Stresi ortadan kaldırmak için yemeye yönelme bilinçli iken, duygularını tam olarak ayrıştıramayan aleksitimik kişiler için otomatik bir reaksiyon olan yönü de bulunmaktadır. Bu duruma "refleksif 
emosyonel yeme” adı verilmiştir. Refleksif emosyonel yeme duyguları tanımada ve duygu alışverişinde zorluk ve kendi duygularının farkında olmama ile belirli bir kognitif özellik olan aleksitimi ile ilişkili bulunmuştur (3).

Yeme bozukluğu olan hastalar sağlıklı kontrollere göre daha aleksitimiktirler (64). TYB'u olan kişilerde aleksitiminin emosyonel yeme için öngörücü olduğu bulunmuştur (65). Bazı çalışmalar aleksitimiyi yeme davranışının kendisinden ziyade yeme bozukluğu olan hastaların psikolojik karakteristikleriyle daha ilişkili bulmuşlardır. Sözgelimi obez bireyler obez olmayan bireylere göre daha aleksitimik bulunmuştur (66). Ancak sadece TYB olmayan obezlerde ölçüldüğünde obezite ve aleksitimi arasında belirgin bir ilişki saptanmamıştır (66), Sonuçta araştırmalar aleksitiminin özellikle yeme bozukluğu olan obez bireylerde öne çıktığını göstermektedir (67).

\section{Kilo Verdirici Tedaviler ve Emosyonel Yeme}

Obezite ve paralel olarak obezite için tedavi arayışları günümüzde giderek artmaktadır. Bu çerçevede diyet ve davranış düzenlemelerinin yanında bariatrik cerrahi de etkili tedavi biçimi olarak gündeme gelmektedir. Kilo verme ile sonuçlanan diyet ya da diğer müdahalelerin emosyonlar ve davranışsal etkileri de araştırılmıştır. Belirgin kilo kaybı ile kalıcı olabilen hem fiziksel hem de davranışsal belirtiler gelişebilmektedir. Bunlar mizaçdeğişiklikleri, depresyon, soğuk intoleransı, saç dökülmesi, karotenemi ve kompulsif egzersiz, yemek ve bedenle aşırı uğraşı, kendilerini diyete rağmen obez hissetme gibi anoreksiyanervoza hastalarında gözlenen benzer düşüncelerdir. Tedavi sonuçlarının iyileştirilmesi için sonuçları öngören değişkenlerin bilinmesi önemli bir noktadır. Emosyonel yeme bu öngörücülerden biri olarak da ele alınmıştır. Emosyonel yemenin, diyet yapanlardan kimin başarısız olmaya kimin başarılı olmaya daha yatkın olduğunu ayrıştırmada etkisi gösterilmiştir(68).

Obezitenin emosyonel özelliklerle ilişkisi dürtüsel

\section{Kaynaklar:}

1. de Kloet AD, Pati D, Wang L, Hiller H, Sumners C, Frazier CJ, Seeley RJ, Herman JP, Woods SC, Krause EG. Angiotensin type la receptors in the paraventricular nucleus of the hypothalamus protect against diet-induced obesity. J Neurosci. 2013;33:4825-33.

2. Lux V, Kendler KS. Deconstructing major depression: a validation study of the DSM-IV symptomatic criteria. Psychol Med. 2010;40:1679-90. özelliklerle ilişkisinden daha güçlüdür ve emosyonel yeme özellikle tedavi arayışında olan obez bireylerde oldukça yaygındır (69). Diyetle kilo verme ve bariatrik cerrahi sonrasında emosyonel yemenin azaldığına dair bazı kanitlar mevcuttur (3). Bu bulgular emosyonel yemenin yeme bozukluklarında önemli rolü olduğunu göstermektedir. Canetti ve ark.'nın çalışmasında emosyonel yemenin bariatrik cerrahi sonuçlarına etkisi incelenmiş ve emosyonel yemenin cerrahi tedavi sonuçları için öngörücü olduğu bulunmuştur. Emosyonel yemesi daha fazla olanlar hem diyet programı hem cerrahi sonrasında daha az kilo vermişlerdir (70). Gerek cerrahi öncesi gerekse sonrasını araştıran çalışmalar, emosyonel yemenin hem önce hem de sonrasında bariatrik cerrahi hastalarında yaygın olduğunu ve bariatrik cerrahi için olumsuz sonlanımla ilişkili bir risk etkeni olduğunu ortaya koymuştur (71). Aynı zamanda bariatrik cerrahi hastalarında mevcut emosyonel yemenin, postoperatif dönemde atıştırma ve otlanma tarzı yeme davranışı ve kontrolsüz yeme ile ilişkili olduğu bulunmuştur (72).

\section{SONUÇ}

Güncel araştırmalarda yeme davranışı ve emosyonlar arasındaki kompleks ilişki hakkındaki bilgilerimiz ağırlıklı olarak yeme bozuklukları ve obezite araştırmalarından kaynaklanmaktadır. Emosyonel yeme, özellikle obezite, yeme bozuklukları, kilo verdirici tedaviler ve diyet konularının anlaşılmasında yardımcı bir kavram gibi durmaktadır. "Emosyonel Yeme” kavramsallaştırmasının günlük pratikte kendine yer bulması ve işlevsel oluşu yapılacak ileri araştırmaları teşvik eder mahiyettedir. Psikiyatrik bozukluklarda gözlenen yeme ve kilo değişiklikleri, ilaç yan etkileri ile ilişkili ya da ilişkisisiz metabolik sendrom ve diyabet, ve kilo verdirici tedavilerle iç içe geçen psikososyal konular da dikkate alındığında emosyonel yeme kavramının daha kapsamlı araştırılması gerekliliği aşikardir.

3. Chesler BE. Emotional eating: a virtually untreated risk factor for outcome following bariatric surgery. Scientific World Journal 2012;365961. doi: 10.1100/2012/365961.

4. Ganley RM. Emotion and eating in obesity: A review of the literature. International Journal of Eating Disorders 1989;8:8343361. 
5. Greeno CG, Wing RR. Stress-induced eating. Psychological Bulletin. 1994;115:444-64.

6. Schachter S, GoldmanR,Gordon A. Effects of fear, food deprivation, and obesity on eating. Journal of Personality and Social Psychology. 1968;10: 91-7.

7. Heatherton TF, Herman CP, Polivy J. Effects of physical threat and ego threat on eating behavior. J PersSoc Psychol. 1991;60:138-43.

8. Ouwens MA, van Strien T, van der Staak CP. Tendency toward overeating and restraint as predictors of food consumption. Appetite. 2003;40:291-8.

9. Telch CF, Agras WS. The effects of short-term food deprivation on caloric intake in eating-disordered subjects. Appetite. 1996;26:22133.

10. Polivy J, Herman CP, McFarlane T. Effects of anxiety on eating: Does palatability moderate distress-induced overeating in dieters? Journal of Abnormal Psychology. 1994;103:505-510.

11. Bekker MH, van de Meerendonk C, MollerusJ.Effects of negative mood induction and impulsivity on self-perceived emotional eating. Int J Eat Disord. 2004;36:461-469.

12. Taylor GJ, Parker JD, Bagby RM, Bourke MP. Relationships between alexithymia and psychological characteristics associated with eating disorders. J Psychosom Res. 1996;41:561-8.

13. Waller G, Matoba M. Emotional eating and eating psychopathology in nonclinical groups: a cross-cultural comparison of women in Japan and the United Kingdom. Int J Eat Disord. 1999;26:333-40.

14. Blair AJ, Lewis VJ, Booth DA. Does emotional eating interfere with success in attempts at weight control? Appetite. 1990;15:151-7.

15. McCrone S, Dennis K, Tomoyasu N, Carroll J. A profile of early versus late onset of obesity in postmenopausal women. J Womens Health Gend Based Med. 2000;9:1007-13.

16. Carver CS, Scheier MF, Weintraub JK. Assessing coping strategies: a theoretically based approach. J PersSoc Psychol. 1989;56:267-83.

17. Henderson NJ, Huon GF. Negative affect and binge eating in overweight women. Br J Health Psychol. 2002;7:77-87.

18. Relations between negative affect, coping, and emotional eating. Spoor ST, Bekker MH, Van Strien T, van Heck GL. Appetite. 2007;48:368-76

19. Mehrabian A. Basic Dimensions for a General Psychological Theory. Oelschlager, Gunn \&Hain, Cambridge.1980.

20. Lyman B. The nutritional values and food group characteristics of food preferred during various emotions. Journal of Psychology. $1982 ; 112 ; 121-7$

21. Patel KA, Schlundt DG. Impact of moods and social context on eating behavior. Appetite. 2001;36,:111-8.

22. Macht M. Characteristics of eating in anger, fear, sadness and joy. Appetite. 1999;33: 129-39.

23. Davis R, Freeman R, Solyom L. Mood and food: an analysis of bulimic episodes. J Psychiatr Res. 1985;19:331-5.

24. Oliver G, Wardle J, Gibson EL. Stress and food choice: a laboratory study. Psychosom Med. 2000;62:853-65.
25. Kelley AE, Schiltz CA. Accessories to addiction: G protein regulators play a key role in cocaine seeking and neuroplasticity. Neuron. 2004;42:181-83.

26. Canetti L, Bachar E, Berry EM. Food and emotion. Behav Processes. 2002;60:157-64

27. SchachterS. Some extraordinary facts about obese humans and rats. Am Psychol. 1971;26:129-144.

28. RudermanAJ.Obesity, anxiety, and food consumption. Addict Behav. 1983;8:235-42

29. Bruch H. Obesity in childhood and personality development. 1941. Obes Res. 1997;5:157-161.

30. Schachter S. Obesity and eating. Internal and external cues differentially affect the eating behavior of obese and normal subjects. Science. 1968 23;161:751-6.

31. Herman CP, Mack D. Restrained and unrestrained eating. J Pers. 1975;43:647-60.

32. Herman CP,Polivy J. Restrained eating. In A. Stunkard (Ed.), Obesity (pp. 208-225). Philadelphia: Saunders. 1980.

33. Waller G, Osman S. Emotional eating and eating psychopathology among non-eating-disordered women. Int $J$ Eat Disord. 1998;23:419-24.

34. Heatherton TF, Baumeister RF. Binge eating as escape from selfawareness. Psychol Bull. 1991;110:86-108.

35. Wallis DJ, Hetherington MM. Stress and eating: the effects of egothreat and cognitive demand on food intake in restrained and emotional eaters. Appetite. 2004;43:39-46

36. Lindeman M, Stark K, KeskivaaraP.Continuum and linearity hypotheses on the relationship between psychopathology and eating disorder symptomatology. Eat Weight Disord. 2001;6:181-7.

37. Polivy J, Herman CP. Distress and eating: why do dieters overeat? Int J Eat Disord. 1999;26:153-64.

38. Abraham SF, BeumontPJ. How patients describe bulimia or binge eating. Psychol Med. 1982;12:625-35.

39. Arnow B, Kenardy J, Agras WS. Binge eating among the obese: a descriptive study. J Behav Med. 1992;15:155-170.

40. Stice E, Presnell K, Spangler D.Risk factors for binge eating onset in adolescent girls: a 2-year prospective investigation. Health Psychol. 2002;21:131-8.

41. Van Strien T, Engels RC, Van Leeuwe J, SnoekHM. The Stice model of overeating: tests in clinical and non-clinical samples. Appetite. 2005;45:205-13.

42. Wolff GE, Crosby RD, Roberts JA, Wittrock DA. Differences in daily stress, mood, coping, and eating behavior in binge eating and nonbinge eating college women. Addict Behav. 2000;25:205-16.

43. Birgegård $\mathrm{A}$, Clinton $\mathrm{D}$, Norring $\mathrm{C}$. Diagnostic issues of binge eating in eating disorders. Eur Eat Disord Rev. 2013;21:175-83.

44. Masheb RM, Grilo CM. Emotional overeating and its associations with eating disorder psychopathology among overweight patients with binge eating disorder. Int J Eat Disord. 2006;39:141-6. 
45. Pyle RL, Mitchell JE, Eckert ED. Bulimia: a report of 34 cases. JClin Psychiatry. 1981;42:60-4.

46. Mitchell JE, Pyle RL, Eckert E, Hatsukami D, Soll E. Bulimia nervosa with and without a history of overweight. J Subst Abuse. 1990;2:369-74.

47. Nolan LJ, Geliebter A. Night eating is associated with emotional and external eating in college students. Eat Behav. 2012;13:202-6.

48. Braet C, Crombez G. Cognitive interference due to food cues in childhood obesity. J Clin Child Adolesc Psychol. 2003;32:32-9.

49. Christensen L. Effects of eating behavior on mood: a review of the literature.Int J Eat Disord. 1993;14:171-83.

50. Macht M, Haupt C, Ellgring H. The perceived function of eating is changed during examination stress: a field study. Eat Behav. 2005;6:109-12.

51. Macht M, Simons G. Emotions and eating in everyday life. Appetite. 2000;35:65-71.

52. Blair AJ, Lewis VJ, Booth DA. Influences on food choice and intake. Commentary from the 1st and 2nd food choice conferences. Prediction of success at weight loss from behaviour, attitudes, emotional eating and self-efficacy. Appetite. 1994;22:277-9.

53. Yanovski SZ, Nelson JE, Dubbert BK, Spitzer RL.Association of binge eating disorder and psychiatric comorbidity in obese subjects. Am J Psychiatry. 1993;150:1472-9.

54. Kaplan HI, Kaplan HS. The psychosomatic concept of obesity. Journal of Nervous and Mental Disease.1957; 125:181-201.

55. Apfeldorfer G, Zermati JP. Cognitive restraint in obesity. History of ideas, clinical description Presse Med. 2001;30:1575-80.

56. Bruch, H. (1973). Eating disorders. Obesity and anorexia nervosa. Riverside: Behavior Science Book Service.

57. Müller J, Dettmer D, MachtM.The Attitudes to Chocolate Questionnaire: psychometric properties and relationship to dimensions of eating. Appetite. 2008;50:499-505.

58. Kenardy J, Arnow B, AgrasWS.Theaversiveness of specific emotional states associated with binge-eating in obese subjects. Aust N Z J Psychiatry. 1996;30:839-44.

59. Bellisle F, Louis-Sylvestre J, Linet N, Rocaboy B, Dalle B, Cheneau F, L'Hinoret D, GuyotL.Anxiety and food intake in men. Psychosom Med. 1990;52:452-7.
60. Foreyt JP, Brunner RL, Goodrick GK, Cutter G, Brownell KD, St JeorST. Psychological correlates of weight fluctuation. Int J Eat Disord. 1995;17:263-75

61. Geliebter A, Aversa A.Emotional eating in overweight, normal weight, and underweight individuals. Eat Behav. 2003;3:341-347.

62. Barrett LF.Solving the emotion paradox: categorization and the experience of emotion. PersSocPsychol Rev. 2006;10:20-46.

63. Schachter S, Singer JE. Cognitive, social, and physiological determinants of emotional state. Psychol Rev. 1962;69:379-99.

64. De Chouly De Lenclave MB, Florequin C, Bailly D. Obesity, alexithymia, psychopathology and binge eating: a comparative. Encephale. 2001; 27:343-50.

65. Zeeck A, Stelzer N, Linster HW, Joos A, Hartmann A. Emotion and eating in binge eating disorder and obesity Eur Eat Disord Rev. 2011;19: 426-37.

66. Pinna F, Lai L, Pirarba S, Orrù W, Velluzzi F, Loviselli A CarpinielloB. Obesity, alexithymia and psychopathology: a casecontrol study. Eat Weight Disord. 2011;16:164-170.

67. Da Ros A, Vinai P, Gentile N, Forza G, Cardetti S. Evaluation of alexithymia and depression in severe obese patients not affected by eating disorders. Eat Weight Disord. 2011;16:24-29.

68. vanStrien T, Koenders PG. How do life style factors relate to general health and overweight? Appetite. 2012;58:265-70.

69. Annagür BB, Orhan FÖ, ÖzerA,Tamam L, Erhan C. Obezitede Dürtüsellik ve Emosyonel Faktörler: BirÖnÇalışma. NöropsikiyatriArşivi. 2012; 49:14-9.

70. Canetti L, Berry EM, Elizur Y. Psychosocial predictors of weight loss and psychological adjustment following bariatric surgery and a weight-loss program: the mediating role of emotional eating.Int J Eat Disord. 2009;42:109-17.

71. Walfish S. Self-assessed emotional factors contributing to increased weight gain in pre-surgical bariatric patients. Obes Surg. 2004;14:1402-5.

72. Colles SL, Dixon JB, O'Brien PE. Grazing and loss of control related to eating: two high-risk factors following bariatric surgery. Obesity. 2008;16:615-22. 